\title{
Now Is the Time for a Rights-Based Approach to Social Work Practice
}

\section{Jane McPherson $^{1}$}

Published online: 3 June 2020

(C) Springer Nature Switzerland AG 2020

Arundhati Roy (2020), the Indian novelist and human rights activist, recently wrote of the current pandemic as an opportunity:

Historically, pandemics have forced humans to break with the past and imagine their world anew. This one is no different. It is a portal, a gateway between one world and the next. We can choose to walk through it, dragging the carcasses of our prejudice and hatred...Or we can walk through lightly, with little luggage, ready to imagine another world. And ready to fight for it.

As social work scholars and educators dedicated to human rights, we stand with the rest of humanity a bit stunned as we pass through this new portal. Though Roy offers it to us as an opportunity, we know that for many, this passage will be difficult. The prospect of leaving certain forms of injustice behind is hopeful, but many of us leave loved ones and livelihoods behind as well. Social workers are dying from the novel coronavirus, universities are slashing budgets, and social service agencies are struggling both to provide services and to make payroll. As we prepare ourselves to take on the challenge of this opportunity, we must take time to care for ourselves, our families, and our communities. Though we may eventually develop immunity to the virus, few of us will be fully immune to its effects.

Still, we cannot let the opportunity pass to imagine and fight for a better world. As Heather Walter-McCabe (2020) argues in her recent call for social work action, "we are needed" (p. 69). But what exactly are we needed to do? As professionals who come into daily contact with individuals experiencing injustice, social workers are needed to use their micro- and macro-level skills to address people's immediate needs while also insisting on a fair redistribution of privilege, power and assets in our societies. In other words, now is the

Jane McPherson

jmcpherson@uga.edu

1 University of Georgia, Athens, GA, USA time for social workers to commit to taking a rights-based approach to their social work practice (Mapp et al. 2019).

What can a rights-based approach bring to the current moment? First, a rights-based approach to assessment allows us to see the havoc wrought by the novel coronavirus through a rights-based lens and focuses us on the impact of discrimination and other rights violations (Mapp et al. 2019). We see clearly how the virus is disproportionate in its impact, how it thrives where racism, ageism, ableism, and other forms of discrimination thrive; how it prefers those who live on the economic edge, who lack the space in which to self-isolate, who live with diseases exacerbated by stress and poor nutrition, and whose work does not easily translate online; and how it particularly menaces migrants and refugees, the homeless, and the imprisoned or detained (Associated Press 2020; Beech and Hubbard 2020; DeParle 2020).

Through a rights-based lens, we see that in many societies access to healthcare, unemployment benefits, housing, social security, education, etc.- - the social and economic rights first promised in the Universal Declaration of Human Rights (United Nations 1948) - are actually privileges reserved for some rather than rights guaranteed to all. Shifting the focus from human needs to human rights requires social workers to see their clients' concerns in larger sociopolitical context and to assess for political issues beyond the standard social or psychiatric ones. Further, it challenges social workers to work in solidarity with their clients in the fight for justice (Mapp et al. 2019). Seeing problems through a rights-based lens leads social workers to set ambitious, justice-focused goals, which may not be easily met: a client's need for a roof over her head may be met by referring her to a shelter; securing her human right to housing requires a long-term commitment to social and political change.

A rights-based approach guides intervention as well as assessment. Rights-based social workers root their practice in the human rights principles of human dignity, nondiscrimination, participation, transparency, and accountability (Androff 2016; McPherson and Abell 2020). Following these principles, rights-based social workers cultivate democratic and clear engagement with their service users. Relationships, built 
on equality and respect, serve to deconstruct traditional power dynamics based on profession, race, income, or other social status (McPherson 2015). This practice of building respectful and engaged partnerships that question the usual distribution of authority creates expectations - within service users and social workers - that all human beings will be listened to and treated with dignity. Solutions may come from the client and everyone's voice matters. These practices that emphasize the importance of all voices could become important crucibles of resistance as many world governments are using the opportunities presented by the current public health crisis to expand their authorities (Gebrekidan 2020).

Rights-based practice with its large goals is necessarily collaborative (McPherson and Abell 2020). To create the justice-focused change, social workers must engage clients, communities, and political leaders. Other professionals are needed too: lawyers, certainly, but also organizers, doctors, educators, researchers, and more. This practice, which requires attention to both micro- and macro-level concerns, demands skills and energy that go beyond what a single human being (even one with social work super powers) is likely to possess.

Rights-based practice is political. It requires advocacy and activism, and this is surely a time when our political action is needed to address the human rights violations and gaps in care and services that the coronavirus has made (even more) visible. As Walter-McCabe (2020) writes about this present moment, "There is no limit to the number of issues that need social work advocacy" (p. 71). Some social workers feel uncomfortable with the call to political action. Indeed, evidence from Bosnia, Romania, and the USA demonstrates that social workers are less comfortable with activism than they are with other aspects of the rights-based practice model (Iovu 2019; McPherson and Abell 2020; Šadić et al. 2020).

This discomfort is something we should all critically examine. Paul Farmer (2005), a physician who advocates for professionals to ally politically with their clients, explains that neutrality is just a "smokescreen" that "wittingly or unwittingly" allies allegedly neutral professionals (in our case, social workers) with the powerful against the interests of the underserved and disenfranchised (p. 26). Social workers should also remember that activism helped build our profession and that we have a tradition of campaigning for civil and economic rights (Piven and Cloward 1978; Reisch 2013).

A human rights-based approach to social work understands our service users as experts and partners, rather than passive recipients of charity and services (Mapp et al. 2019). It also empowers - and challenges - us to promote our core professional values, even (and especially) when those values may be threatened by austerity-promoting public policies (Reynaert et al. 2019) and authoritarian power grabs. Today, as we address the fallout from the coronavirus in a time of reduced social spending and increasing social inequality (Ferguson et al. 2018), it is time for social work to embrace the rightsbased approach.

The articles in this issue help us to envision this work in different contexts. Smith and Doolan help us see how seemingly standardized accounting procedures can increase stigmatization and hardship, while Ruskus et al. explore the dynamics of power between Lithuanian social workers and their clients with disabilities. We continue to see how migrants are vulnerable to human rights violations whether they are being deported from the USA (Smith et al.), rendered stateless in Haiti (Popescu et al.), or fleeing the war in Syria (Smajlovic \& Murphy). The limits of the legal framework to address human rights concerns are illustrated by Mafa et al. using the example of revenge porn, while Fukushima and Heffernan provide hopeful information on how organizations can use a human rights framework.

Arundhati Roy asks us to imagine the world on the other side of the portal. We need to pass through that door envisioning the expansion of human rights for all. And willing to work for it.

\section{References}

Androff, D. (2016). Practicing rights: human rights-based approaches to social work practice. New York: Routledge.

Associated Press. (2020). Racial toll of virus grows even starker as more data emerges. U.S. News \& World Report. https://www.usnews. com/news/us/articles/2020-04-18/racial-toll-of-virus-grows-evenstarker-as-more-data-emerges

Beech, H. \& Hubbard, B. (2020). Unprepared for the worst: world's most vulnerable brace for virus. The New York Times. https://www. nytimes.com/2020/03/26/world/asia/coronavirus-refugees-campsbangladesh.html

DeParle, J. (2020). The coronavirus class divide: space and privacy. The New York Times. https://www.nytimes.com/2020/04/12/us/politics/ coronavirus-poverty-privacy.html

Farmer, P. (2005). Pathologies of power: health, human rights, and the new war on the poor. Berkeley: University of California Press.

Ferguson, I., Ioakimidis, V. \& Lavalette, M. (2018). Global social work in a political context: Radical perspectives, Bristol, Policy Press.

Gebrekidan, S. (2020). For autocrats, and others, coronavirus is a chance to grab even more power. The New York Times. https://www. nytimes.com/2020/03/30/world/europe/coronavirus-governmentspower.html

Iovu, M.B. (2019). Usage of human rights practice by Romanian social workers, International Social Work. Epub ahead of print 27 March. https://doi.org/10.1177/0020872819828429.

Mapp, S., McPherson, J., Androff, D. A., \& Gatenio Gabel, S. (2019). Social work is a human rights profession. Social Work, 64(3), 259269. https://doi.org/10.1093/sw/swz023.

McPherson, J. (2015). Human rights practice in social work: a U.S. social worker looks to Brazil for leadership. European Journal of Social Work, 18(4), 599-612. https://doi.org/10.1080/13691457.2014. 947245.

McPherson, J., \& Abell, N. (2020). Measuring rights-based practice: introducing the human rights methods in social work scales. British Journal of Social Work, 50(1), 222-242. https://doi.org/10. 1093/bjsw/bcz132. 
Piven, F. F., \& Cloward, R. A. (1978). Poor people's movements: why they succeed and why they fail. New York: Vintage.

Reisch, M. (2013). What is the future of social work? Critical and Radical Social Work, 1(1), 67-85. https://doi.org/10.1332/ 204986013 X665974.

Reynaert, D., Dijkstra, P., Knevel, J., Hartman, J., Tirions, M., Geraghty, C., Gradener, J., Lochtenberg, M., \& van den Hoven, R. (2019). Human rights at the heart of the social work curriculum. Social Work Education, 38(1), 21-33. https://doi.org/10.1080/02615479. 2018.1554033.

Roy, A. (2020). The pandemic is a portal. The Financial Times. https:// www.ft.com/content/10d8f5e8-74eb-11ea-95fe-fcd274e920ca
Šadić, S., McPherson, J., Villarreal-Otálora, T., \& Bašić, S. (2020). Rights-based social work in Bosnia and Herzegovina: validating tools for education and practice. International Social Work. https:// doi.org/10.1177/0020872820912310.

United Nations. (1948). Universal declaration of human rights. https:// www.un.org/en/universal-declaration-human-rights/index.html

Walter-McCabe, H. A. (2020). Coronavirus pandemic calls for an immediate social work response. Social Work in Public Health, 35(3), 69 72. https://doi.org/10.1080/19371918.2020.1751533.

Publisher's Note Springer Nature remains neutral with regard to jurisdictional claims in published maps and institutional affiliations. 